\title{
Effects of the application of biosolids on some chemical, biological and physical properties in an Andisol from southern Chile
}

\author{
I. Salazar ${ }^{*}$, D. Millar ${ }^{2}$, V. Lara², M. Nuñez ${ }^{2}$, M. Parada², M. Alvear ${ }^{1}$ and J. Baraona ${ }^{2}$ \\ ${ }^{1}$ Departamento de Ciencias Químicas y Recursos Naturales, Facultad de Ingeniería, Ciencias y Administración, \\ Universidad de La Frontera, Casilla 54-D, Temuco, Chile. ${ }^{2}$ Departamento de Ciencias Agronómicas y Recursos \\ Naturales, Facultad de Ciencias Agropecuarias y Forestales, Universidad de La Frontera, Casilla 54-D. \\ Temuco. Chile. ${ }^{*}$ Corresponding author: itilier@ufro.cl
}

\begin{abstract}
An important issue for soil conservation and waste disposal is the use of biosolids in agriculture and for land reclamation. Most biosolids contain valuable nutrients that could be used to improve soil fertility. The aim of this work was to establish the effects of the application of biosolids on some chemical, biological and physical properties in an Andisol from southern Chile. This study was carried out under farm conditions during the wheat (Triticum aestivum) growing cycle. Five land plots of $10 \times 4 \mathrm{~m}$ each were prepared: control soil (TAT), chemical fertilisation (TAF) and applications equivalent to 30 ton biosolids/ha (TA30), 60 ton biosolids/ ha (TA60) and 90 ton biosolids ha ${ }^{-1}$ (TA90). The soil samples of both treatment and non-treatment groups were collected after the application of biosolids, after sowing and before the wheat harvest. The evaluated chemical soil parameters were modified by the application of biosolids. Base levels of organic carbon, $\mathrm{pH}$ and $\mathrm{P}$ increased. Biological activity measured by the evolution of $\mathrm{C}-\mathrm{CO}_{2}$ followed the sequence TA90 $>$ TA $60>$ TA $30>$ TAF $>$ TAT. The physical properties evaluated, namely water infiltration rate, accumulated infiltration and water retention capacity, all increased with the increasing dose of biosolids. The results show a strong correlation between the biosolids dose applied and the change in the soil properties studied.
\end{abstract}

Keywords: Biosolids, Organic matter, Biosolids application, Organic amendment. 


\section{Introduction}

Agricultural practices often lead to a gradual decrease in the organic matter content of the soil and result in a decrease in soil fertility because of impoverishment of its physical, chemical and biological properties (Perucci et al., 1997). These agricultural practices have an impact on the soil microflora, which is important for understanding the biological and biochemical processes that contribute to soil fertility.

Biological activity is influenced by the transformation of organic matter, soil degradation and soil structure along with other factors. Biological activity was evaluated through $\mathrm{CO}_{2}$ evolution, and a high correlation was shown between respiration, microbial biomass and the carbon content of the soil (Witter et al., 1993).

Humans have used organic waste since ancient times to fertilise the soil used for agriculture and livestock production (Castro et al., 2007). Water purification produces large amounts of waste or sludge, the disposal of which is important because some of its components may be converted into nutrients or pollutants that can have a positive or negative impact, respectively, on the environment.

Agricultural use is a satisfactory alternative that can provide a double benefit:

1) elimination of urban organic waste from the environment without adverse effects on the ecological balance, and

2) incorporation of the organic matter and its nutrients into commercially cultivated soil (Celis et al., 2006).

Sludge and other waste biosolids are rich in organic matter that contains sufficient nitrogen and phosphorus to make them potentially useful as fertilisers and sources of organic matter (Mazzarino, 2003). They can also improve the physical properties of the soil, such as the bulk density, the porous structure and water re- tention, all of which may be reflected in an increase in crop yields (Barbarick et al., 2004). It is known that the practice of overworking cultivated areas causes a progressive loss of organic matter in the soil with damaging consequences: diminished fertility and topsoil, reduced nutrient retention capacity and erosion. These may become irreversible in some zones with serious short and long-term environmental consequences potentially affecting their future viability.

This research provides information about the effects of the application of biosolids to the soil at different doses $(30,60$, and 90 ton biosolids/ha) on the soil's biological, physical and chemical properties in one wheat crop cycle.

\section{Materials and methods}

Experimental plots of land measuring $10 \times 4 \mathrm{~m}$ and with slopes $<2 \%$ were established in Los Prados Serie Andisols, 38 58'21" South and 72 7'21.7" West. The land had been meadowland for at least four years. The approximate average temperature was $10.5^{\circ} \mathrm{C}$. The climate range was between moderately warm and rainy with 1,200 $\mathrm{mm}$ annual precipitation.

The study included five treatments. There were two untreated soils: one control without the application of fertiliser (TAT) and the other fertilised with $735 \mathrm{~kg} \mathrm{ha}^{-1}$ triple super phosphate and $920 \mathrm{~kg} \mathrm{ha}^{-1}$ of potassium sulphate (TAF). The other three soils received doses of biosolids from the Water Treatment Plant, Vilcún, equivalent to 30, 60 and 90 ton dry matter $\mathrm{ha}^{-1}$ (TA30, TA60 and TA90, respectively). The plots were divided into experimental units of $13 \mathrm{~m}^{2}$ surface area. Treatments were performed in triplicate. The crop used was Triticum aestivum, var. Quijote. Three soil samples were taken from each plot before and after sowing and before harvesting in the summer 
period. In each sample, chemical, active biological and physical parameters were determined (Sadzawka et al., 2004). Chemical analyses of the soil, the biosolids and the soil under treatment were performed according to the regulations for the management of sludge generated at sewage treatment plants (Supreme Decree $N^{\circ}$ 004). Biological activity was evaluated based on the $\mathrm{CO}_{2}$ evolution (Stotzky, 1965) for $50 \mathrm{~g}$ of each soil sample (humidity $60 \%$ ) incubated at $25 \pm$ $2^{\circ} \mathrm{C}$ and trapped in $15 \mathrm{~mL}$ of $\mathrm{NaOH} 0.1 \mathrm{M}$. Carbonate was precipitated with $\mathrm{BaCl}_{2} 0.375 \mathrm{M}$, and $\mathrm{NaOH}$ residue was titrated with $\mathrm{HCl} 0.1 \mathrm{M}$.

The global microbiological activity was determined based on the accumulated values of $\mathrm{C}-\mathrm{CO}_{2}$ over a period of time according to the potential model used by Dommergues (1968). The evolution of organic $\mathrm{C}$ to $\mathrm{CO}_{2}$ is expressed according to the formula $\mathrm{C}=\mathrm{k}^{*} \mathrm{t}^{\mathrm{m}}$, where $\mathrm{C}$ is the loss in $\mathrm{mg}$ of organic $\mathrm{C}$ with $\mathrm{CO}_{2}$ accumulated over time for $100 \mathrm{~g}$ of dry soil; $\mathrm{k}$ is the first day constant emission in $\mathrm{mg}$ of $\mathrm{C}-\mathrm{CO}_{2 /} 100 \mathrm{~g}^{-1}$ of dry soil; $\mathrm{t}$ is the number of days; and $\mathrm{m}$ is the constant that determines the form of the curve. The values of $k$ and $\mathrm{m}$ were obtained by applying the simple regression of the linear equation. The microbiological activity was calculated according to Levi-Minzi et al. (1990) and was the result of $\mathrm{k}^{*} \mathrm{~m}$.

The accumulated water infiltration in the soil and the infiltration rate were measured using an infiltrometer (a metal cylinder measuring $20 \mathrm{~cm}$ diameter by
$30 \mathrm{~cm}$ length). The water retention in the soil at depths of 20 and $60 \mathrm{~cm}$ was determined every 15 days according to the gravimetric content. The field water capacity (FWC) was equal to retention of $1 / 3 \mathrm{~atm}$, corresponding to the maximum water retention capacity of the soil. The permanent wilting point (PWP) was equal to $15 \mathrm{~atm}$, corresponding to the minimum water content available for cultivation.

\section{Results and discussion}

Table 1 shows the results of the biosolids analysis used in this investigation. The total organic carbon (TOC) content is $25 \pm 5 \mathrm{mg} \mathrm{kg}^{-1}$ and supplies organic $\mathrm{C}$ to the soil. The $\mathrm{pH}_{\left(\mathrm{H}_{2} \mathrm{O}\right)}$ of the raw sludge was 7.2 \pm 0.8 , which rose to $\mathrm{pH}_{\left(\mathrm{CaCl}_{2}\right)} 10.8 \pm 0.8$ with the addition of lime. The biosolids used in this trial were stabilised (with the addition of lime) according to Chilean law (Supreme Decree $N^{\circ}$ 004). This represents a $66.7 \%$ increase in the $\mathrm{pH}$ value because of the effect of the lime on the raw sludge. The lime sanitises the sludge while providing calcium to the soil under investigation $\left(\mathrm{pH}_{\left(\mathrm{H}_{2} \mathrm{O}\right)} 5.7 \pm 0.1\right)$ (Table 2). This assists the production of leaf biomass in the unit. The addition of biosolids to the soil with the exchange base contents, nitrogen, phosphorus, boron and heavy metals at the micronutrient level makes it economically interesting as a fertiliser supplement.

Table 1. Composition of biosolids from wastewater treatment plant.

\begin{tabular}{lcc}
\hline Chemical Parameters & Biosolids & \\
\hline & Range & Average \\
\hline $\mathrm{TOC}\left(\mathrm{mg} \mathrm{kg}^{-1}\right)$ & $20-30$ & 25 \\
$\mathrm{pH}\left(\mathrm{H}_{2} \mathrm{O}\right)$ & $6.3-8.0$ & 7.2 \\
$\mathrm{pH}\left(\mathrm{CaCl}_{2}\right)$ & $10.0-11.6$ & 10.8 \\
$\mathrm{Conductivity} \mathrm{(deciSiemens/cm)}$ & $1.0-6.0$ & 3.5 \\
$\mathrm{Nt}(\%)$ & $3.0-6.0$ & 4.5 \\
$\mathrm{Pt}(\%)$ & $0.9-1.6$ & 1.3 \\
$\mathrm{~K}(\%)$ & $0.2-0.8$ & 0.5 \\
$\mathrm{Na}\left(\mathrm{mg} \mathrm{kg}^{-1}\right)$ & $2.0-4.5$ & 3.3 \\
\hline
\end{tabular}


Continued...

\begin{tabular}{|c|c|c|}
\hline \multirow[t]{2}{*}{ Chemical Parameters } & \multicolumn{2}{|c|}{ Biosolids } \\
\hline & Range & Average \\
\hline $\mathrm{Ca}\left(\mathrm{mg} \mathrm{kg}^{-1}\right)$ & $2.0-1.0$ & 1.5 \\
\hline $\operatorname{Mg}\left(\mathrm{mg} \mathrm{kg}^{-1}\right)$ & $1.1-3.2$ & 2.2 \\
\hline $\mathrm{S}\left(\mathrm{mg} \mathrm{kg}^{-1}\right)$ & $0.2-1.2$ & 0.7 \\
\hline $\mathrm{Cd}\left(\mathrm{mg} \mathrm{kg}^{-1}\right)$ & & \\
\hline $\mathrm{Cu}\left(\mathrm{mg} \mathrm{kg}^{-1}\right)$ & & \\
\hline $\mathrm{Hg}\left(\mathrm{mg} \mathrm{kg}^{-1}\right)$ & & \\
\hline $\mathrm{Pb}\left(\mathrm{mg} \mathrm{kg}^{-1}\right)$ & & \\
\hline $\mathrm{Ni}\left(\mathrm{mg} \mathrm{kg}^{-1}\right)$ & & \\
\hline $\mathrm{Zn}\left(\mathrm{mg} \mathrm{kg}^{-1}\right)$ & & \\
\hline As $\left(\mathrm{mg} \mathrm{kg}^{-1}\right)$ & & \\
\hline $\mathrm{Se}\left(\mathrm{mg} \mathrm{kg}^{-1}\right)$ & & \\
\hline
\end{tabular}

As shown in Table 2, the chemical parameters of the control soil (TAT), TOC and bases increase proportionally with the dose of biosolids from 30 to 90 ton ha ${ }^{-1}$. This contrasts with the fertilised soil (TAF), which shows no change except for an increase in the base phosphorus level. The increase in the base phosphorus level is attributable to the high content of this element in the biosolids. The reference ground (TAT) contained $5.3 \mathrm{ppm} P$, and the fertilised soil (TAF) had an increase in $\mathrm{P}$ of $2 \mathrm{ppm}$ and applying fertiliser (TAF) $\mathrm{P}$ level increased by 2 ppm P, also At the end of the first year of the wheat cycle, the application of 30, 60 and 90 ton biosolids/ha resulted in increases of 16, 23 and $44 \mathrm{ppm}$ $\mathrm{P}$, respectively, compared with the control.

Table 2. Soil and treatment analysis

\begin{tabular}{lcccc}
\hline Treatments & TOC & $\mathbf{p H}_{\left(\mathrm{H}_{\mathbf{2}} \mathbf{O}\right)}$ & Bases & $\mathbf{P}$ \\
\hline \multicolumn{3}{c}{$\mathbf{\%}$} & & \multicolumn{2}{c}{$\mathbf{~ m g ~ k g}^{-\mathbf{1}}$} \\
\hline TAT & $9.3 \pm 0,2$ & $5.7 \pm 0.1$ & $3.7 \pm 0.5$ & $5.3 \pm 1.3$ \\
TAF & $9.3 \pm 0.3$ & $5.7 \pm 0.1$ & $4.3 \pm 0.8$ & $7.3 \pm 2.3$ \\
TA30 & $10.3 \pm 1.6$ & $5.7 \pm 0.3$ & $11.8 \pm 0.5$ & $21.3 \pm 4.7$ \\
TA60 & $11.2 \pm 3.3$ & $5.9 \pm 0.5$ & $17.2 \pm 3.7$ & $28.0 \pm 0.1$ \\
TA90 & $11.4 \pm 3.7$ & $6.0 \pm 0.4$ & $23.5 \pm 1.1$ & $49.1 \pm 0.7$ \\
\hline
\end{tabular}

TAT: Control soil; TAF: Fertilised soil; TA30, soil with 30 ton biosolids ha ${ }^{-1}$; TA60, soil with 60 ton biosolids ha ${ }^{-1}$; TA90, soil with 90 ton biosolids ha ${ }^{-1}$.

Figure 1 presents the $\mathrm{C}-\mathrm{CO}_{2}$ evolution in soil fertilised with the three treatments: TA30, TA60 and TA90, 15 days after incorporation of biosolids, the soil fertilised with chemical fertiliser (TAF) and the control soil (TAT). There are no great differences compared to the TAT, indicating that the incorporation of the biosolids into the soil requires more time or that some effects may be outside the parameters mea- sured. The system requires an initial stabilisation period because of the microbial stress produced by the change in $\mathrm{pH}$ and the new microenvironmental conditions affecting the native microbes. This was confirmed by the high levels of $\mathrm{C}-\mathrm{CO}_{2}$ produced 15 days after initiation of the experiments in the five systems when no great differences were observed among them (Alvarez et al., 1999, Torri et al., 2003). 


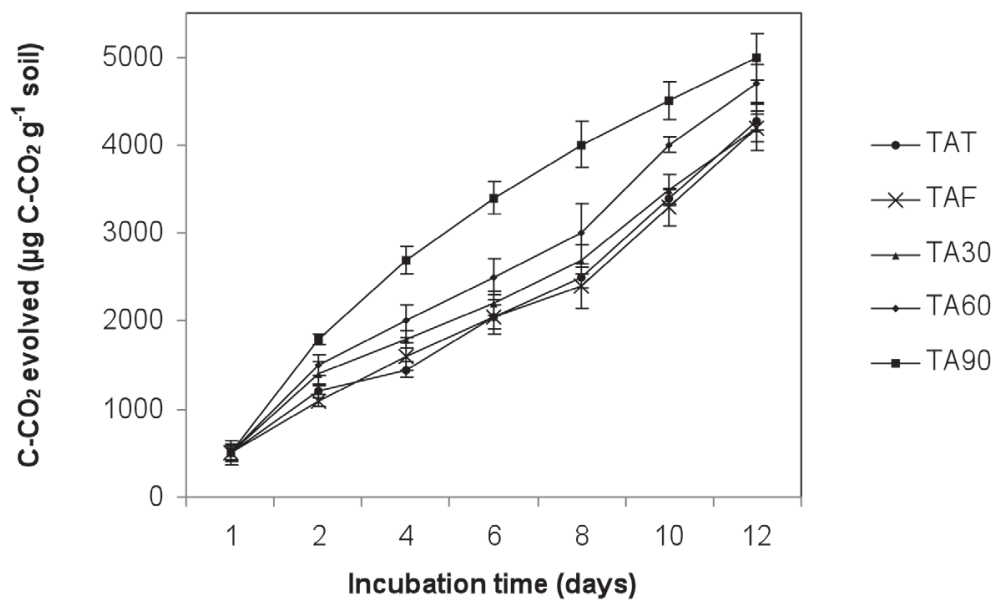

Figure 1. Accumulated evolution of organic carbon $\mathrm{C}-\mathrm{CO}_{2}$ over time in the control without fertilisation, fertilised, with 30 ton ha ${ }^{-1}, 60$ ton ha- ${ }^{-1}$ and 90 ton ha' ${ }^{-1}$ of biosolids before planting.

The condition of the treated soil system changed one month after treatment and after being sown, which helped biosolids-soil homogenisation.

Figure 2 shows the sequence of $\mathrm{C}-\mathrm{CO}_{2}$ evolution: TA90 $>$ TA60 $>$ TA30 $>$ TAT $>$ TAF. For time periods less than 6 days, the fertilised soil (TAF) presented less microbial respiration because of the presence of chemical fertilisers; in systems with added biosolids where there was additional organic matter available as a source of energy for microorganisms, microbial respiration increased.

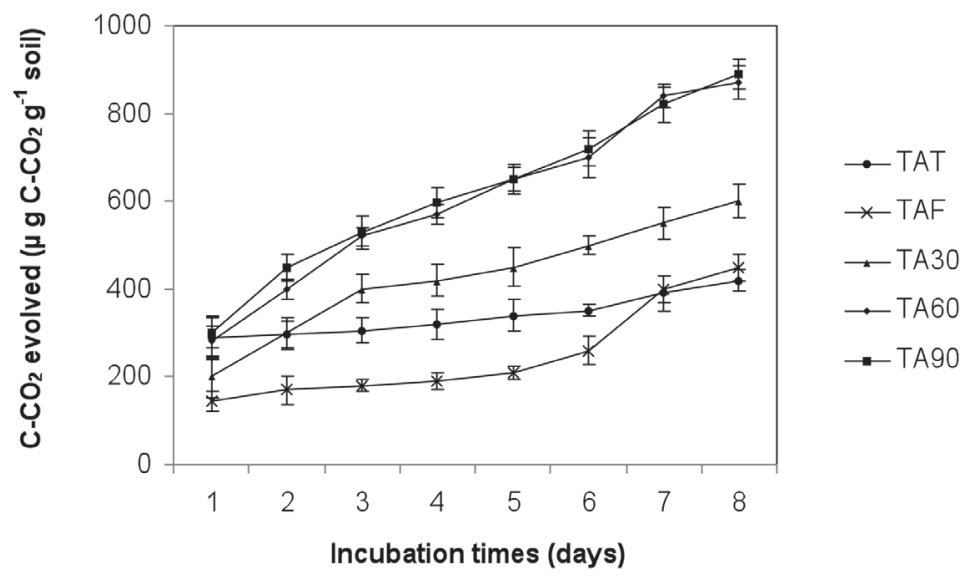

Figure 2. Accumulated evolution of organic carbon $\mathrm{C}-\mathrm{CO}_{2}$ over time in the control without fertilisation, fertilised with 30 ton ha ${ }^{-1}, 60$ ton ha ${ }^{-1}$ and 90 ton ha ${ }^{-1}$ of biosolids after planting. 
Figure 3 shows that four months after the incorporation of biosolids into the soil and before harvesting, TA90, in particular, presented the highest level of microbial activity. The relationship shown in
Figure 2 confirms the high availability of labile organic matter contributed by the biosolids. This activity is proportional to the amount of additional carbon.

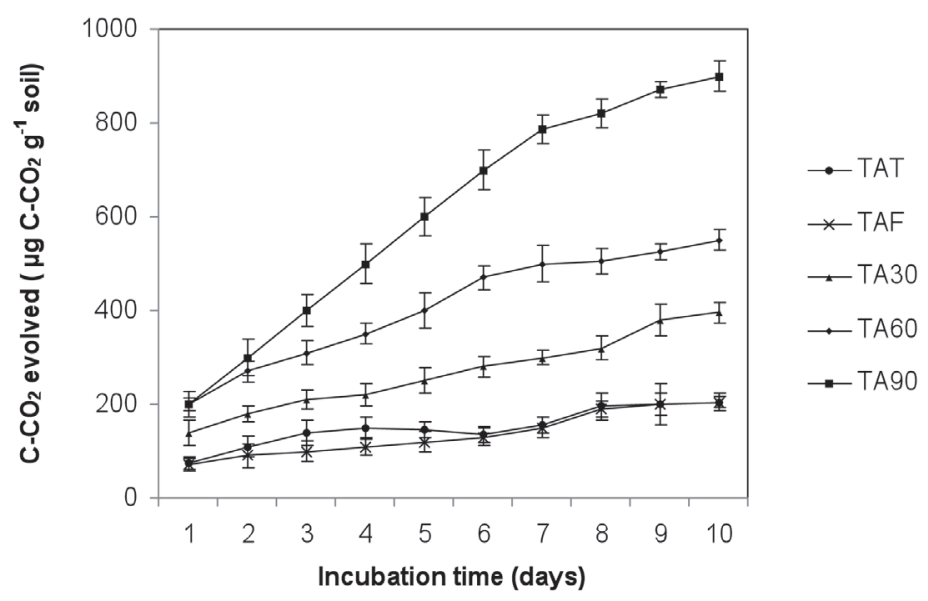

Figure 3. Accumulated evolution of organic carbon $\mathrm{C}-\mathrm{CO}_{2}$ over time in the control without fertilisation, fertilised with 30 ton $\mathrm{ha}^{-1}, 60$ ton $\mathrm{ha}^{-1}$ and 90 ton $\mathrm{ha}^{-1}$ of biosolids before harvesting.

The accumulated $\mathrm{C}-\mathrm{CO}_{2}$ values over incubation time, according to the equation $\mathrm{C}=\mathrm{k} * \mathrm{t}^{\mathrm{m}}$ proposed by Dommergues (1968), were adjusted and linearized to obtain the values of $\mathrm{k}$ and $\mathrm{m}$ by simple regression and thereby permitting microbiological activity to be known. Table 3 shows the high $\mathrm{CO}_{2}$ emission on the first day of incubation, which is represented by the $\mathrm{k}$ values of the treated units: 537.6
$\mathrm{mgC}-\mathrm{CO}_{2} / 100 \mathrm{~g}$ dry soil for TA90; $555.3 \mathrm{mgC}-\mathrm{CO}_{2}$ $/ 100 \mathrm{~g}$ dry soil for TA60; and $374.2 \mathrm{mgC}-\mathrm{CO}_{2} / 100 \mathrm{~g}$ dry soil for TA30. These were followed by the TAT where the native microorganisms have not been altered by either positive or adverse environmental conditions. In contrast, the unit with added chemicals (TAF) presented lower $\mathrm{C}-\mathrm{CO}_{2}$ emissions on the first day of incubation.

Table 3. $\mathrm{K}$ and $\mathrm{m}$ values ( $\mathrm{mg} \mathrm{C}-\mathrm{CO}_{2} 100 \mathrm{~g}^{-1}$ soil dry) estimated by applied simple regression to the series of soil and treatment data

\begin{tabular}{lcccc}
\hline Treatment & \multicolumn{2}{c}{ Post-sowing } & \multicolumn{2}{c}{ Pre-harvest } \\
\hline TAT & $\mathbf{~}$ & $\mathbf{~ m}$ & $\mathbf{K}$ & $\mathbf{~ m}$ \\
TAF & $274.97 \pm 0.8$ & $0.14 \pm 0.8$ & $0.48 \pm 0.8$ & $0.48 \pm 0.8$ \\
TA30 & $118.87 \pm 0.5$ & $0.47 \pm 0.5$ & $0.51 \pm 0.5$ & $0.51 \pm 0.5$ \\
TA60 & $374.20 \pm 0.5$ & $0.15 \pm 0.5$ & $0.42 \pm 0.5$ & $0.42 \pm 0.5$ \\
TA90 & $555.30 \pm 0.4$ & $0.13 \pm 0.4$ & $0.54 \pm 0.4$ & $0.54 \pm 0.4$ \\
\hline
\end{tabular}

TAT: Control soil; TAF: Fertilised soil; TA30, soil with the addition of 30 ton biosolids ha ${ }^{-1}$;A60, soil with the addition of 60 ton biosolids ha ${ }^{-1}$; TA90: soil with the addition of 90 ton biosolids ha-1. 
The global microbiological activity, calculated as the product of the parameters $\mathrm{k}$ and $\mathrm{m}$, is presented in Table 4, which shows in numerical form the same information presented in the previous figures and in Table 3. The highest microbiological activity was observed in the treated units, followed by TAT. The least activity occurred in the fertilised units (TAF). TAF also presented strongly diminished activity before the harvest, most likely because of the exhaustion of the labile organic carbon available for microorganisms (García-Gil et al., 2004).

Table 4. Microbiological soil activity and its respective treatments.

\begin{tabular}{lcc}
\hline Treatment & \multicolumn{2}{c}{ Microbiological Activity (k m) } \\
\hline & Post-sowing & Pre-harvest \\
\hline TAT & $275.0 \pm 0.8$ & $91.7 \pm 0.8$ \\
TAF & $119.3 \pm 0.5$ & $67.5 \pm 0.5$ \\
TA30 & $374.4 \pm 0.5$ & $143.6 \pm 0.5$ \\
TA60 & $555.4 \pm 0.4$ & $176.7 \pm 0.4$ \\
TA90 & $537.7 \pm 0.4$ & $176.7 \pm 0.4$ \\
\hline
\end{tabular}

Regarding the physical properties evaluated, Moffet et al. (2005) observed that both the basic infiltration rate and cumulative infiltration increased at the highest dose of application of biosolids on degraded soils. This phenomenon coincided with the results obtained in this research, which showed significant differences (Figure 4) between the control and treatments of 60 and 90 ton biosolids ha ${ }^{-1}$.

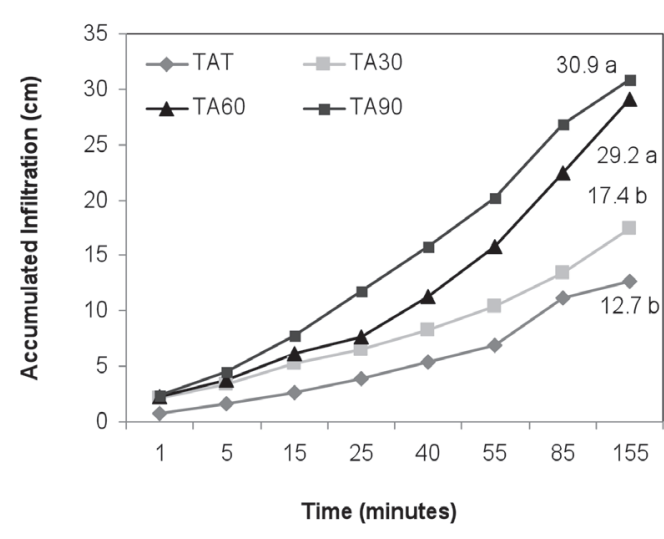

Figure 4. Accumulated soil infiltration under different treatments over time.

The basic infiltration rate (steady state infiltration rate) (Figure 5) was higher in the treatments with higher biosolids doses, reflecting the facilitation of the entrance of water into the soil by the biosolids. The results also suggest a possible reduction in the risk of erosion in exposed soils.

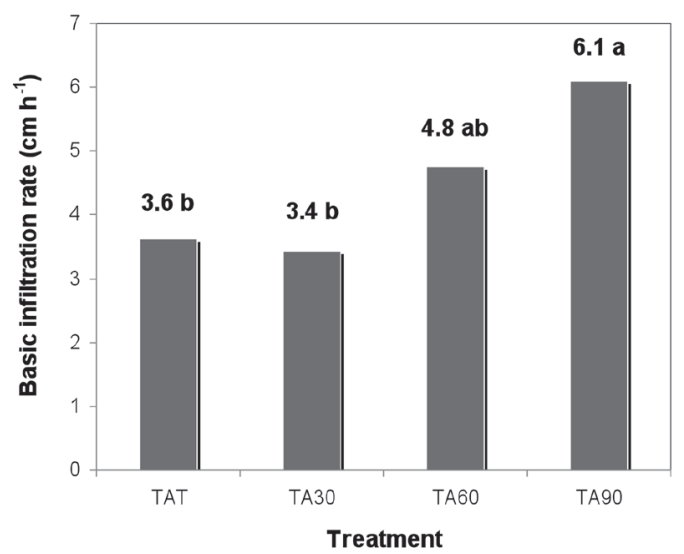

Figure 5. Basic infiltration rate for each treatment. Different letters indicate significant differences between treatments (Duncan, $\alpha=0.5$ ). 
There was no effect on the water retention properties of the soil in the first year of biosolids application. The values available in the literature for the parameters field water capacity and permanent wilting point
(CIREN, 2002) are frequently high in Andisols in the Araucanía Region in Chile and become higher at greater depth (Table 5).

Table 5. Water retention properties at 20 and $60 \mathrm{~cm}$ depth in the study systems.

\begin{tabular}{|c|c|c|c|c|c|}
\hline \multicolumn{6}{|c|}{ Soil water content $(\%)$ at $20 \mathrm{~cm}$ depth } \\
\hline & TAT & TAF & TA30 & TA60 & TA90 \\
\hline $\begin{array}{l}\text { FWC } \\
(1 / 3 \mathrm{~atm})\end{array}$ & $66.70 \mathrm{ab}$ & $69.60 \mathrm{ab}$ & $64.45 b$ & $74.30 \mathrm{a}$ & $70.70 \mathrm{ab}$ \\
\hline $\begin{array}{l}\text { PWP } \\
(15 \mathrm{~atm})\end{array}$ & $43.00 \mathrm{a}$ & $49.35 \mathrm{a}$ & $45.35 \mathrm{a}$ & $46.75 \mathrm{a}$ & $48.75 \mathrm{a}$ \\
\hline Available water content & $23.70 \mathrm{ab}$ & $20.40 b$ & $19.10 \mathrm{~b}$ & $27.55 \mathrm{a}$ & $22.00 \mathrm{ab}$ \\
\hline \multicolumn{6}{|c|}{ Soil water content $(\%)$ at $60 \mathrm{~cm}$ depth } \\
\hline & TAT & TAF & TA30 & TA60 & TA90 \\
\hline $\begin{array}{l}\text { FWC } \\
(1 / 3 \mathrm{~atm})\end{array}$ & $94.90 \mathrm{a}$ & $87.70 \mathrm{a}$ & $92.70 \mathrm{a}$ & $92.90 \mathrm{a}$ & $94.20 \mathrm{a}$ \\
\hline $\begin{array}{l}\text { PWP } \\
(15 \mathrm{~atm})\end{array}$ & $68.30 \mathrm{a}$ & $63.20 \mathrm{a}$ & $60.90 \mathrm{a}$ & $63.40 \mathrm{a}$ & $63.20 \mathrm{a}$ \\
\hline Available water content* & $26.60 \mathrm{a}$ & $24.50 \mathrm{a}$ & $31.80 \mathrm{a}$ & $29.50 \mathrm{a}$ & $31.00 \mathrm{a}$ \\
\hline
\end{tabular}

Different letters indicate significant differences between units (Duncan, $\alpha=0.5$ ).

* Available water content corresponds to difference between FWC and PWP.

When the evolution of the gravimetric water content at $20 \mathrm{~cm}$ soil depth in dry conditions (rainfall only, without seasonal irrigation) is analysed based on the sample data (Figure 6), the treatments with biosolids tend to present greater humidity than the treated test units. Data from the latest sampling dates had values close to PWP and show the benefits of the application of biosolids because this application generates a hydric support condition for the plants and reduces the risk of water stress. The treatments TA60 and TA90 had water content superior to FW and close to saturation, which may indicate some risk of excess humidity in the surface zone of the soil where aeration is normally required for cultivation. The permanence of this system over time needs to be evaluated to provide further support for treatment with biosolids (Crush et al., 2005).

The FWC, PWP and available water content of the different treatments were statistically similar, indicating that the effect of the treatments on these variables would be longer-term.

There were significant differences between these parameters at 20 and $60 \mathrm{~cm}$ soil depth because of the higher water retention capacity, which is attributable to the higher percentage of clay at depth $(19.1 \%$ clay at $20 \mathrm{~cm}$ depth and $24.1 \%$ clay at $60 \mathrm{~cm}$ depth). 


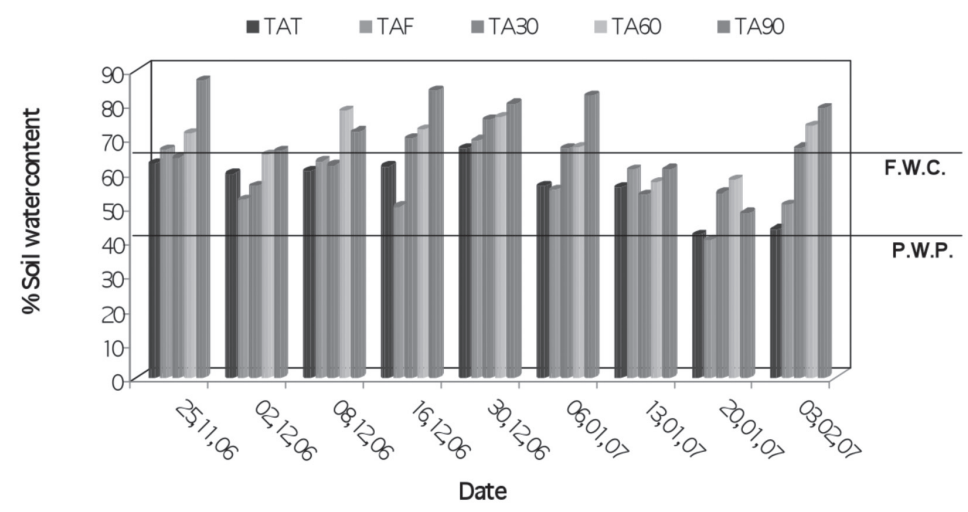

Figure 6. Evolution of water content at $20 \mathrm{~cm}$ depth.

The evolution of the water content at $60 \mathrm{~cm}$ depth (Figure 7) did not differ much with the various treatments, except on the latest sampling dates when the treated units were close to PWP. There is a marked tendency towards water contents close to saturation at $20 \mathrm{~cm}$ depth in treatments with a larger dose of biosolids, which interestingly is not noted in this deeper layer.

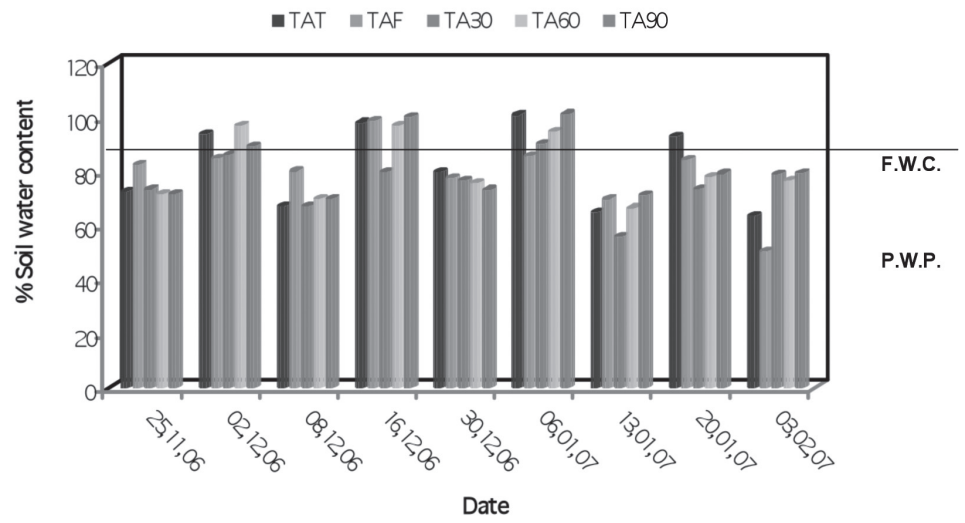

Figure 7. Evolution of water content at $60 \mathrm{~cm}$ depth.

\section{Conclusion}

The incorporation of biosolids into Los Prados Serie Andisols in the Araucanía Region, Chile shows changes in the biological, physical and chemical parameters of the soil, including increased nutritional content; greater biological activity; and an improve- ment in the physical parameters of the soil. The latter is expressed primarily in increased water retention and infiltrometric properties of the soil with benefits for cultivation. It should be noted that the possibility of excess water retention and risk of anoxia from the application of high doses of biosolids was not assessed. 


\section{Acknowledgements}

This investigation was financed by the DIUFRO Project N ${ }^{\circ} 120620$ and Empresa Aguas Araucanía, S.A. Temuco. It was also financed by Project DIUFRO $\mathrm{N}^{\circ}$ IN-13-00 and DIUFRO N² 2004.

\section{References}

Alvarez, R., Alconada, M., Lavado, R. 1999. Sewage sludge effects on carbon dioxide-carbon production from a desurfaced soil. Communications in soil Science and Plant Analysis. 30(13-14), 1861-1866.

Barbarick, K., Doxtader, K., Redente, E., Brobst, R. 2004. Biosolids effects on microbial activity in shrubland and grassland soils. Soil Science. 169(3),176-187.

Castro, C. P., Henriquez, O., Freres, R. 2007. Posibilidades de aplicacion de lodos o biosolidos a los suelos del sector norte de la Region Metropolitana de Santiago. Revista de geografia Norte Grande. 37, 35-45.

Celis, J., Sandoval, M., Zagal, E., Briones, M. 2006. Effect of sewage sludge and salmon wastes applied to a Patagonian soil on lettuce (Leactuce sativa L.) germination. R.C. Suelo nutr.Veg. 6(3), 13-25.

CIREN 2002. Descripcion de suelos. Estudio Agrologico IX region. Publicacion $\mathrm{N}^{\circ}$ 122. 343p. Crush, J.R., Sarathchandra, U., Donnison, A. 2006. Effect of plant growth on

dehydration rates and microbial populations in sewage biosolids. Bioresource Technology. 97, 24472452.

Dommergues, Y. 1968. Degagement tellurique de CO2. Measure et signification. Annales de l'Institut Pasteur. 4(115): 626-656

Garcia-Gil, J.C., Plaza, C., Senesi, N., Brunetti, G., Polo, A. 2004. Effects of sewage sludge amendment on humic acids and microbiological prop- erties of a semiard Mediterranean soil. Biology Fertility of Soils. 39, 320-328.

Levi-Minzi, R., Riffaldi, R., Saviozzi. A. 1990. Carbon mineralization in soil amended with different organic materials. Agriculture, Ecosystems and Environment. 31, 325-335.

Mazzarino, M.J. 2003. Uso Agricola de biosolidos en Argentina, la experiencia de Bariloche. Noticias del agua y Medio Ambiente (Buenos Aires).

Ministerio Secretaria General de la Presidencia de la Republica. Reglamento para el manejo de lodos de Plantas de Tratamiento de Aguas Servidas. D.S. No 004, 2009.

Moffet, C.A., Zartman, R.E., Wester, D.B., Sosebee, R.E. 2005. Surface biosolids application: Effects on infiltration, erosion and organic carbon in chihuahuan desert grasslands and shrublands. Journal of Environmental Quality, 34, 299-311

Perucci, P., Bonciarelli, U., Santilocchi, R., Bianchi, A.A. 1997. Effect of rotation nitrogen fertilization and management of crop residues on some chemical microbiological and biochemical properties of soil. Biology Fertility of Soils 24, 311-316.

Sadzawka, A., Carrasco, M., Grez, R., Mora, M. 2004. Métodos de análisis recomendados para los suelos y lodos chilenos. Sociedad Chilena de Ciencia del Suelo.

Stotzky, G. 1965. Microbial respiration. In: Black CA (ed.) Methods of soil analysis. ASA. CSSA, SSSA, Madison, Wis., pp 1550-1570

Torri, S., Alvarez, R., Lavado, R. 2003. Mineralization of carbon from sewage sludge in three soils of the Argentine Pampas. Communications in soil Science and Plant Analysis.34(13-14), 2035-2043.

Witter, E. Martensson, A.M., Garcia, U. 1993. Size of the soil microbial biomass in a long-term field experiment as affected by different $\mathrm{N}$-fertilizers and organic manures. Soil Biochemistry 25(6), 659-669. 